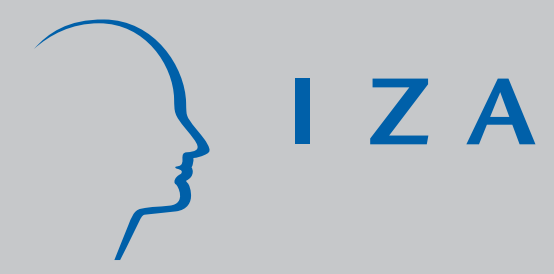

IZADP No. 1030

Determinants of Income Mobility and

Household Poverty Dynamics in South Africa

Ingrid Woolard

Stephan Klasen

February 2004 


\title{
Determinants of Income Mobility and Household Poverty Dynamics in South Africa
}

\author{
Ingrid Woolard \\ Human Sciences Research Council \\ and University of Port Elizabeth, South Africa \\ Stephan Klasen \\ University of Göttingen and IZA Bonn
}

\author{
Discussion Paper No. 1030 \\ February 2004
}

IZA
P.O. Box 7240
53072 Bonn
Germany

Phone: +49-228-3894-0

Fax: +49-228-3894-180

Email: iza@iza.org

\begin{abstract}
Any opinions expressed here are those of the author(s) and not those of the institute. Research disseminated by IZA may include views on policy, but the institute itself takes no institutional policy positions.
\end{abstract}

The Institute for the Study of Labor (IZA) in Bonn is a local and virtual international research center and a place of communication between science, politics and business. IZA is an independent nonprofit company supported by Deutsche Post World Net. The center is associated with the University of Bonn and offers a stimulating research environment through its research networks, research support, and visitors and doctoral programs. IZA engages in (i) original and internationally competitive research in all fields of labor economics, (ii) development of policy concepts, and (iii) dissemination of research results and concepts to the interested public.

IZA Discussion Papers often represent preliminary work and are circulated to encourage discussion. Citation of such a paper should account for its provisional character. A revised version may be available on the IZA website (www.iza.org) or directly from the author. 


\section{ABSTRACT \\ Determinants of Income Mobility and Household Poverty Dynamics in South Africa*}

In this paper we analyse household income mobility dynamics among Africans in South Africa's most populous province, Kwazulu-Natal, between 1993 and 1998. Compared to industrialized and most developing countries, mobility has been quite high, as might have been expected after the transition in South Africa. This finding is robust when measurement error is controlled for. When disaggregating the sources of mobility, we find that demographic changes and employment changes account for a most of the mobility observed which is related to rapidly shifting household boundaries and a very volatile labour market in an environment of high unemployment. Using a multivariate analysis, we see that transitory incomes play a large role. We also find four types of poverty traps, associated with large initial household size, poor initial education, poor initial asset endowment and poor initial employment access that dominate the otherwise observed regression towards to the mean.

JEL Classification: D63, J12, J15, J6

Keywords: $\quad$ mobility, poverty, South Africa, household structure

Corresponding author:

Stephan Klasen

Department of Economics

University of Göttingen

Platz der Göttinger Sieben 3

37073 Göttingen

Germany

Tel.: +49551397303

Email: sklasen@uni-goettingen.de

\footnotetext{
* We would like to thank Mark Misselhorn for excellent research assistance, Neil McCulloch, Bob Baulch, Francois Bourguignon, Michael Burda, David Hulme, Stephen Jenkins, and participants at seminars and conferences at the Universities of Munich, Paris, Manchester, and Berlin for helpful comments and discussion.
} 


\section{Introduction}

As an upper middle income country with a per capita GNP of $\$ 3020$ in 2000, South Africa fares extremely poorly on international comparisons of poverty and other social indicators (World Bank, 2001; Klasen, 2002). Much of this poor record is related to the legacy of apartheid which produced very high inequality in South Africa. South Africa's Gini coefficient of 0.60 is among the highest anywhere in the world (Klasen, 2002). Reducing poverty and inequality are consequently obvious areas of concern for policy-makers in the post-apartheid governments.

An issue that is discussed less, is inter-temporal income mobility - who is getting ahead, who is falling behind, who is standing still, and why? This is of particular relevance in the South African context for two reasons. First, because the postapartheid government promised to reduce poverty and racial disparities it implies that they were aiming in the process to increase mobility, with particular emphasis on enabling upward mobility of previously marginalized Africans (Government of South Africa, 1994). Policies explicitly aimed at generating such upward mobility of Africans were affirmative action legislation, racial equalization and expansion of education spending, the expansion of a social safety net for Africans including the introduction of a child maintenance grant for the poor, greater labour market protection for low-skilled workers, a land reform programme for poor rural and a housing subsidy for poor urban dwellers, expansion of water supply, electricity, and other infrastructure to previously under-served areas, and a macroeconomic reform package that was to deliver faster growth with redistribution. ${ }^{1}$ To what extent these policies have succeeded so far and which groups of Africans appear to have benefited the most are questions that deserve closer scrutiny.

A second reason to study mobility is related to the government's policies to reduce poverty and vulnerability. Here the government was concerned about increasing the level and reducing the variability of incomes of the poorest South Africans. In particular, it adopted policies that were aimed at reducing the dependence of poor

\footnotetext{
${ }^{1}$ See Klasen (2002) for a discussion of these policies.
} 
people's well-being on the vagaries of the labour market as well as demographic and other shocks. ${ }^{2}$ Consequently, the importance of demographic and economic events on mobility should be carefully examined. Given the fluidity of household boundaries in South Africa that are affected by a variety of demographic changes as well as prevailing high unemployment, we expect demographic events and employment changes to play a significant role in accounting for mobility in South Africa (Case and Deaton, 1998; Klasen and Woolard, 2001).

Here we apply a framework developed for studying earnings mobility (see for example Lillard and Willis, 1978; Gottschalk, 1982) to equivalised household incomes to measure the degree of mobility observed between 1993 and 1998 for African households in KwaZulu-Natal, South Africa's most populous province. This paper focuses on the 1003 African households in the KwaZulu-Natal Income Dynamics Study (KIDS) which collected follow-up data on households in KwaZuluNatal that had previously formed part of the 1993 Project for Statistics on Living Standards and Development (PSLSD) survey.

Given that we have only two observations per household, measurement error might well influence our results. Consequently, we use a variety of procedures to test and, to the extent possible, correct for measurement error and examine the robustness of our results. Our controls for measurement error do not necessarily provide unbiased estimates but will help us get a sense of the magnitude of possible biases and thus the robustness of results, a strategy suggested, among others, by Bound, Brown, and Mathiowetz (2001).

\section{Analytical Issues and Findings}

In contrast to the voluminous theoretical and applied income inequality literature, the literature on the measurement and interpretation of mobility is more limited and generally more ad hoc (Fields and Ok, 1999). Important distinctions are made

\footnotetext{
2 Among these are the generous old age (social) pensions of the government, public works programmes, disaster relief, child grants, and disability grants.
} 
between relative and absolute mobility. The former examines changes in rank of households between two periods and is thus mainly concerned with the ability of individuals to move up (and down) in the rankings of incomes while the latter examines absolute changes in income between two periods and thus is additionally concerned with changes in absolute well-being (and poverty). For these reasons, we will report on both in this paper with our regression analysis being focused on absolute mobility as this conveys information on changes in rank as well as on the dynamics of poverty.

As far as measures of mobility are concerned, one first needs to distinguish between what Cowell and Schluter (1998) call single-stage and two-stage indices. Single-stage indices consider the entire distribution in both years and examine mobility using that entire distribution, while two-stage indices first allocate individuals to income groups (either exogenously fixed income groups or endogenously determined ones like quintiles) and then examines mobility between these groups. Examples of singlestage indices are the correlation coefficient of incomes between two periods, Shorrock's rigidity index, Fields and Ok's measures, and King's measure (Fields, 2001; Cowell and Schluter, 1998). ${ }^{3}$ They have the advantage of using all available information inherent in the actual distributions and thus give the most comprehensive assessment of mobility. They have the disadvantage, however, of being particularly sensitive to measurement error which is a particular problem when data from only two waves are available, as happens to be the case here. The index which, in simulation studies, was least sensitive is Shorrock's rigidity index using the Gini coefficient (Cowell and Schluter, 1998) which compares the Gini of the average income between the periods with the weighted average of the Gini in each period. It is defined as:

$$
R=\frac{G(x+y)}{\left(\mu_{x} G_{x}+\mu_{y} G_{y}\right) /\left(\mu_{x}+\mu_{y}\right)}
$$

\footnotetext{
${ }^{3}$ For a careful discussion of the axioms of these measures and their inter-relationships, see Fields and Ok (1999) and Fields (2001).
} 
where $\mathrm{G}(\mathrm{x})$ refers to the Gini in the first period and $\mu$ to mean income. A value of one would mean no mobility at all, while 0 would indicate perfect mobility. We will use this measure to compare our results with other studies.

Regarding two-stage indices, the most commonly used measure is the transition matrix and indices derived from it. For a transition matrix, the data are divided into $n$ equally sized income classes (e.g. deciles or quintiles) which are endogenously determined for each year. Let $P$ be a matrix of $n \times n$ transitions, the $i j$ th element of which, $P_{i j}$, is the percentage in the income class $i$ at time $\mathrm{t}_{0}$ of those who at time $\mathrm{t}_{1}$ were in class $j$. The units which moved from one income class to another $(i \neq j)$ between time $\mathrm{t}_{0}$ and time $\mathrm{t}_{1} \mathrm{I}$ will refer to as "mobiles". Those who remain in their original income class will be called "immobiles". Mobiles who experienced a positive change in relative well-being $(i<j)$ will be referred to as "winners" as opposed to "losers" $(i>j)$.

While sometimes the brackets of a transition matrix are exogenously fixed income classes, the more common method are endogenously determined income groups based on quantiles of the distribution in a given year (such as quintiles or deciles). The advantage of the transition matrix is that it can nicely summarize mobility at various points in the distribution which is harder to gauge from a single index. It also turns out to be more robust to measurement error (Cowell and Schluter, 1998). There are serious costs as well, including the disregard of important information, such as income changes within a bracket and the different absolute income changes that underlie a change in income bracket (Fields and Ok, 1999). ${ }^{4}$

4 This last point can be important in international comparisons of mobility. In a country with low inequality, the same transition matrix may mean much smaller changes in absolute income levels compared to a country with very high inequality. To the extent one wants to capture these absolute changes as well, a transition matrix may not be the right tool. Despite these problems, the advantages of transition matrices are considerable.

The choice of income groups in these transition matrices is largely arbitrary and, in general, tends to take the form prevalent in the literature to allow for the comparison of results. The most popular choices seem to be quintiles and deciles. Nevertheless, the choice of groups influences the results. The smaller (in terms of income range) the brackets, the more likely that people will move between brackets and thus mobility will appear larger. Thus using deciles usually will generate higher perceived mobility than quintiles. Here we selected quintiles rather than deciles because the data-set is quite small. 
Lastly, there is the question of the appropriate income concept for mobility analyses, in particular the choice between incomes and expenditures. The case for incomes is that this is the only way one can analyse sources of mobility (particularly in order to distinguish between demographic and economic events) which is an important part of our analysis here. Moreover in some contexts income might actually be more accurately reported than expenditures or the latter are not readily available (Fields et al. (2002) and Glewwe, Gragnolati and Zaman (forthcoming). On the other hand expenditures are typically a better guide to longer-term well-being of the household (or its 'permanent income') as household will exercise some consumption smoothing and use savings and dissavings to deal with erratic incomes (Deaton, 1997). If we are interested in mobility in these longer-term incomes, expenditures are clearly preferred. Moreover expenditures might, in most cases, be more accurately captured, particularly among the poor who have relatively constant and well-known expenditures on relatively few items while their incomes can be very erratic und unpredictable (Ravallion, 1992, Deaton, 1997, Klasen, 2000). We have access to income and expenditure data and will use both, thereby also pointing to the differences between them which gives some indication on the importance of transitory income shocks as well as measurement error issues.

There are relatively few studies on income mobility in developing countries and even fewer that are roughly comparable. This is partly due to the paucity of reliable panel data sets although increasing numbers of such data sets are becoming available. ${ }^{5}$ Unfortunately many of these panels have very few waves where issues of measurement error are particularly pertinent (Deaton, 1997). Moreover most analyses focus, for obvious reasons, particularly on poverty dynamics rather than on household income mobility more generally (e.g. Jalan and Ravallion, 2000; Dercon and Krishnan, 2000; Scott, 2000; Justino and Lichfield, 2002, McCulloch and Calandrino, 2002).

\footnotetext{
${ }^{5}$ See for example, the special issue of the Journal of Development Studies in August 2000 which includes papers on a number of panel data sets as well as Fields et al. (2002) and the contributions in this special issue.
} 
The studies that exist generally suggest that income mobility in developing countries is higher than in industrialized countries, particularly at the bottom end of the distribution (e.g. Dercon and Krishnan, 2000; Fields, 2001). They also seem to suggest increasing mobility over time in most places. Panel data from Peru based on expenditures points to increased mobility in the 1990s (Fields, 2001). Data from rural China point towards rapidly increasing mobility from very low levels in the 1980s (Nee, 1994) and generally very high mobility at the low end of the distribution (McCulloch and Calandrino, 2002). These studies as well as studies from Chile and Malaysia suggest that education, changes in employment and the demographic composition of the household play a large role in explaining existing mobility and in distinguishing between the transient and the chronic poor (Fields, 2001).

There are three studies we know of that examine income mobility in South Africa using the same data set. The focus of Carter and May (2001) is on movements into and out of poverty in relation to the asset base of the poor, asset and entitlement shocks. They exclusively rely on expenditure data and use transition matrices with exogenously fixed boundaries. They find considerable mobility between 1993 and 1998 and attempt to distinguish between structural and stochastic causes for this mobility. ${ }^{6}$ Our study differs by analysing overall income mobility (but including movements into and out of poverty), the disaggregation of mobility into demographic and economic events, the use of income and expenditure information, and the thorough analysis of measurement error issues.

The second study, by Fields et al. (2002), analyses household income dynamics in four countries, including South Africa using the KIDS data. The study uses only (per capita) household income and is focused on trying to determine whether there is convergence of household incomes between the two periods considered. In the South African context, such convergence is found. In that context,

\footnotetext{
${ }^{6}$ Structurally poor are people whose predicted incomes are below the poverty line while stochastically poor are people whose predicted incomes are above the poverty line but who experienced a negative stochastic shock. It is unclear to what extent one can distinguish these stochastic elements because of measurement error problems. Also, by relying exclusively on expenditures, they do not address the problems and issues of inconsistency between expenditures and incomes in the two years (see below).
} 
it also examines the issue of measurement error and finds that this can have a significant influence on the measured convergence but is unlikely to overturn the sizable convergence found in the South African data. The third study, also by Fields et al. (2003) is a companion paper to the above study which looks at the determinants of household income change and considers initial demographic and labour market conditions as well as their changes and finds that changes in the employment status of the household head as well as initial income have the largest impact on income changes.

Our study differs from their interesting comparative analysis by considering incomes and expenditures, by focusing on South Africa, by providing a thorough sensitivity analysis using different income concepts, by adjusting our welfare measure by household size and composition, by considering a larger set of covariates (with particular relevance to the South African situation) when examining determinants of income change, and by explicitly considering the possibility of poverty dynamics and traps.

\section{Data and Measurement Issues}

The sample data used in this chapter consist of the 1003 African households in KwaZulu-Natal (KZN) that were interviewed in both the 1993 PSLSD and 1998 KIDS surveys. Sample attrition between the two periods is surprisingly low. $85 \%$ of Africans in rural areas and $90 \%$ of Africans in urban areas who had participated in 1993 could be re-interviewed in 1998, despite the fact that the survey was not originally designed as a panel. Two types of attrition took place: Households who were known to have moved away (40\%) and households for which there was no information (60\%). Maluccio, Thomas, and Haddad (1999) show that the former do not differ substantially from the sample that was traced while the latter had lower per capita expenditure in the first period than the sample that was traced. It is a priori 
unclear to what extent this might bias mobility estimates. ${ }^{7}$ Given the very low overall attrition, the bias should not be very large. ${ }^{8}$

KwaZulu-Natal (KZN) is South Africa's most populous of nine provinces, containing about $20 \%$ of South Africa's population. It also contains much of the social and racial stratification present in all of South Africa. In particular the province includes a wealthy metropolitan area (Durban) with poor shantytowns surrounding it, a poor and largely rural former homeland (KwaZulu) with high levels of unemployment and poverty. Poverty as well as inequality within the province appear to be relatively similar to the national level (Leibbrandt and Woolard, 1999). Table 1 shows that Africans in KZN are comparable to Africans elsewhere, although the share coming from former homelands is higher, as is the unemployment rate and the poverty rate in 1993. The table also shows that Africans in 1993 were doing much worse than other population groups (the mean income for all races is much higher than the African mean income) and that income poverty fell for Africans by some 14 percentage points while mean income rose considerably. ${ }^{9}$

${ }^{7}$ If their households were doing particularly poorly and this is the reason for their disappearance from the data set (as is often the case in such panel settings), then this might slightly overestimate mobility and thus underestimate the impact of poverty traps we identify later on. But since we are speaking at most of $7 \%$ of households, the likely bias is small.

${ }^{8}$ The re-survey also showed that a few households in 1993 never existed but had been invented by the enumerators. Subsequent qualitative work showed that entire communities had been fabricated in both 1993 and 1998. As a result, a total of 6 clusters have been dropped from the sample. This has significantly reduced the urban African sample to only 198 households.

${ }^{9}$ Using expenditure data, poverty is believed to have risen (see below and Carter and May, 2001). 
Table 1: Comparisons of Sample with Africans and all races in South Africa

\begin{tabular}{|l|r|r|r|r|}
\hline & $\begin{array}{l}\text { 1993-Africans } \\
\text { in KZN }\end{array}$ & 1993-Africans & 1993-all races & $\begin{array}{l}1998-\text { Africans } \\
\text { in KZN }\end{array}$ \\
\hline \% Households in urban areas & 21.9 & 37.1 & 34.7 & 22.6 \\
\hline $\begin{array}{l}\text { \% Household in (former) } \\
\text { homelands }\end{array}$ & 84.3 & 56.1 & 40.1 & 47.3 \\
\hline Unemployment Rate & 49.3 & 38.2 & 29.8 & 48.3 \\
\hline Poverty Rate (income)* & 57.8 & 44.0 & 32.9 & 410.52 \\
\hline Mean adult equivalent income & 246.60 & 392.07 & 823.72 & 281.56 \\
\hline $\begin{array}{l}\text { Mean adult equivalent } \\
\text { expenditure }\end{array}$ & 305.51 & 401.55 & 719.80 & \\
\hline
\end{tabular}

*: poverty rate is based on R212 per adult equivalent in 1993 Rands.

Our unit of analysis is the household and the income variable used is disposable equivalized net income using the following formula for dealing with economies of scale and adult equivalence, commonly used for poverty and welfare analysis in South Africa (May, Carter \& Posel, 1995; Roberts, 2000):

Adult equivalent income $=\frac{\text { Household income }}{(\text { Adults }+0.5 \text { children })^{0.9}}$

The expenditure variable uses the same adult equivalence procedure. Both the expenditure and income variable used imputations either for missing data or for items where there is only an implied income stream, particularly the income stream one derives from living in one's own home (or living rent free in someone else's home). In the case of housing, these income streams were imputed and added both on the expenditure side as well as on the income side. They make up $4 \%$ of expenditures and 7\% of incomes in 1993 and 13\% of expenditures and $15.4 \%$ of incomes in 1998. This rising share of imputations is somewhat worrying as it is unclear that the value of housing or the quality of housing stock rose that much in these five years. In addition, on the income side, quite a few missing income components were imputed, often using regression-based methods. ${ }^{10}$

\footnotetext{
${ }^{10}$ They make up another $3 \%$ of income in 1998 and $1 \%$ of expenditures.
} 
Almost two-thirds (63\%) of the sample reported that household income had increased over the period, while only $39 \%$ reported an increase in expenditures. Real median adult equivalent income for African households increased by $24 \%$ over the five-year period, while median monthly expenditures fell by $21 \%$. While some of this discrepancy can be real and relates to the timing of the survey (seasonality and economic cycle), changes in perceptions of permanent incomes (and thus expenditures) and the large role of transitory incomes, this large discrepancy in levels and trends raises some questions about the reliability of the data. ${ }^{11}$

These discrepancies could also indicate that measurement error is significant. To address the issue of measurement error we use the following procedures:

a) We replicate all of our analyses using incomes and expenditures to see to what extent the results differ. Given the large discrepancy between incomes and expenditures, this procedure alone should provide some bound on possible measurement error.

b) We purge the 1993 and 1998 labour income data by specifying an earnings regressions of hourly earnings on gender, location, industry, age, age square, education and throwing out all observations that are outside two standard deviations from the point estimate of this earnings regression. The earnings regressions have a good fit (adjusted $\mathrm{R}^{2}$ around 0.5) and confirm the usual findings from the human capital literature (regressions available on request). Using this procedure, we end up eliminating about $5 \%$ of observations.

\footnotetext{
11 There is reason to believe that the expenditure figures in 1998 are somewhat understated. The income figures in 1993 were similarly understated which can contribute to this converse movement in these aggregates. In particular, the 1998 income and expenditure figures seem to tally very well, while the 1993 figures do not. In 1993 expenditures exceeded incomes by more then $20 \%$ in $40 \%$ of households, which seems too high even in the face of income smoothing and suggests that incomes were not completely listed. Similarly in 1998 the list of expenditure items solicited in the questionnaire was reduced and median and mean food spending is reported to have declined by nearly $40 \%$ between 1993 and 1998 which seems unlikely given the high poverty and large food shares of households. Thus understated incomes in 1993 may mean that income growth was smaller than reported and understated expenditures might mean that expenditure decline was smaller so that the two trends at least converge. All the more is it important to address issues of measurement error.
} 
c) We use an instrumental variable approach to measurement error. Using a regression of household adult equivalent income (and expenditure) on household size, demographic structure, average education, age of household head, female headship, location, land and other asset ownership, and the employment and unemployment situation of adults, we predict household incomes in 1993 and 1998 and assess our mobility using these predicted incomes. Clearly we are thereby throwing away quite a lot of true mobility that would not be captured by these regressions but this approach should give us sense of the maximum extent to which our measurement error affects incomes or expenditures. ${ }^{12}$

d) We eliminate the imputed parts of the income and expenditure aggregate and then perform our analysis on the sample without imputations on the presumption that imputations might be bringing in a fair amount of measurement error (Jarvis and Jenkins, 1998). ${ }^{13}$

\section{The extent of household income mobility 1993-1998}

We begin by reporting Shorrock's rigidity index using the Gini coefficient for our various income concepts to get a feel for the data and the changes over time. The Ginis for the two years are presented as well as those for the average income and the rigidity index which is calculated using the formula above. Several items in Table 2 are noteworthy. First, there is a considerable difference between inequality when using income and expenditures. The expenditure Gini is much lower than the income Gini, a finding that appears to be the case in most countries (e.g. Deininger and Squire, 1998). This is to be expected as consumption smoothing makes expenditure

\footnotetext{
12 Carter and May (2001) interpreted these differences between predicted and actual incomes (in a slightly different regression framework using expenditures) in their entirety as stochastic elements of income that can make households stochastically poor or non-poor. Instead of using predicted incomes for each year, we also ran a fixed effects regression based on the pooled data for both years. Due to the great importance of the fixed effects, using this regression (predicted) mobility was greatly reduced to levels that did not seem plausible. Given the changing nature of households, it was also not clear whether such a fixed effects approach was warranted.

${ }^{13}$ In particular, we drop observations with imputed incomes and subtract imputed housing services from both expenditures and incomes but retain these observations without the imputations. Please note that we use this procedure in addition to purging outliers based on the wage regressions.
} 
less erratic and thus less unequal and as recall error among respondents tends to be inequality-reducing when it comes to expenditures (the poor report it well, the rich forget items) while recall error is inequality-enhancing when it comes to incomes (the rich tend to have more stable and predictable incomes than the poor whose income is more erratic and therefore often tends to be understated, e.g. Bound et al. 2001, Deaton, 1997). The two measures do agree, however, on rising inequality among Africans between 1993 and 1998 which is to be expected given that the educated and upwardly mobile Africans are likely to benefit more quickly from the end of racebased restrictions (and affirmative action) than poor and uneducated rural dwellers (Klasen, 2002; Carter and May, 2001).

Second, the rigidity index for incomes and expenditures indicates a fairly high degree of mobility, when compared to mature industrialized countries where the rigidity index is usually around 0.95 or above for countries such as the US, the United Kingdom, Germany, or Sweden (e.g. Jenkins and Jarvis, 1998; Eriksson and Pettersson, 2000). It is closer to countries undergoing rapidly structural change such as Spain in the 1990s, where it was estimated to be around 0.9 on a comparable basis (Cantó 2000).

Third, while the various adjustments for presumed measurement error do affect the Gini coefficients considerably, particularly in the case of leaving out imputations for the income Gini and using predicted incomes for both income and expenditure Ginis, the rigidity index is scarcely affected by any of these adjustments, particularly on the income side. ${ }^{14}$ This seems to suggest that to the extent there is measurement error in the data, it seems to be positively correlated across time and thus only has a muted impact on mobility, which was also, for example, found for longitudinal earnings data in the US (Bound and Krueger, 1991; Bound et al., 1994; see also Fields et al. 2002).

Lastly, despite large differences in inequality between incomes and expenditures, the rigidity index is quite similar, although somewhat lower for expenditures. Thus in the

\footnotetext{
${ }^{14}$ It is somewhat more affected on the expenditure side, but here too only the predicted expenditures really have a significant effect.
} 
five years between 1993 and 1998, incomes and expenditures experienced the same, relatively high mobility pattern. ${ }^{15}$

\section{Table 2: Rigidity Index using the Gini Coefficient and Various Income Definitions}

\begin{tabular}{|l|l|c|c|c|c|}
\hline & & 1993 Gini & 1998 Gini & Average Y Gini & Rigidity Index \\
\hline Incomes & Unpurged & 0.460 & 0.549 & 0.461 & 0.895 \\
\hline & Purged & 0.461 & 0.545 & 0.458 & 0.894 \\
\hline & W/out Imputations & 0.461 & 0.577 & 0.468 & 0.884 \\
\hline & Predicted & 0.414 & 0.398 & 0.367 & 0.907 \\
\hline Expenditures & Unpurged & 0.304 & 0.379 & 0.294 & 0.867 \\
\hline & Purged & 0.304 & 0.378 & 0.293 & 0.865 \\
\hline & W/out Imputations & 0.292 & 0.364 & 0.272 & 0.842 \\
\hline & Predicted & 0.233 & 0.255 & 0.218 & 0.896 \\
\hline
\end{tabular}

Note: The purged data refer to the income and expenditure data where labour income was outside of two standard deviations from predictions based on a wage regression. Without imputations drops implied income and expenditure streams associated with housing and drops observation where other incomes where imputed. Predicted is based on the household income (expenditure) regression.

While these statistics already tell us quite a lot, we want to unpack mobility beyond this one measure and thus turn to transition matrices for a more disaggregated look. The quintile mobility matrix below (Table 3 ) shows the distribution of households by quintile for 1993 and 1998. (Quintiles are numbered from 1 for poorest to 5 for richest.) It can be seen that $56 \%$ of households who were in the richest quintile in 1993 remained there in 1998 and another 23\% moved down just one quintile. Likewise, $34 \%$ of those who began in the poorest quintile were still there 5 years later and another $25.5 \%$ had moved up just one quintile. It is immediately evident that there is less mobility in the top and bottom quintile than in the middle of the distribution. This is, however, unsurprising given that the bottom (top) quintile can only stay in the same quintile or move up (down); also, furthermore the income range that make up the quintile is much larger for the richest quintile where the right-hand tail is particularly large which is the reason why persistence in that group is

\footnotetext{
${ }^{15}$ One may wonder how this is consistent with the lower Gini reported for expenditures in each year and the presumption that consumption smoothing makes expenditures less erratic and unequal. It may be the case that over the medium term horizon of five years, (presumed) permanent incomes have changed as much or possibly even more than actual incomes and thus are reflected in the relatively high mobility in expenditures.
} 
particularly high. ${ }^{16}$ These figures also suggest quite a high degree of income mobility among Africans in KwaZulu-Natal which is certainly higher than that observed in most industrialized countries (e.g. Jarvis and Jenkins, 1997), but also higher than in rural China between 1978 and 1983, Malaysia between 1967 and 1976, and Peru in the 1980s and 1990s (Fields, 2001). It is quite similar, however, to rural China between 1983 and 1989 although the structure of mobility appears to be somewhat different. $^{17}$

When purging the data of outliers based on our earnings regressions, we get more persistence and very large movements between income groups, particularly downward movements, are now reduced. For example, there are now fewer households that jumped up but particularly down two, three, or even four quintiles. As a result, we get quite a lot more persistence, particularly in the top quintile where the data now look more like those of industrialized countries. At the bottom, however, mobility continues to be much higher than in industrialized countries.

\footnotetext{
${ }^{16}$ While in the lower four quintiles, the income brackets cover a range of 90-400 Rands in adult equivalent incomes, the top quintile ranges from 792 to 11300 Rands. Clearly, it is harder to leave this much larger bracket than the lower ones.

${ }^{17}$ In rural China, (downward) mobility from the top quintile is higher than in South Africa. This may partly be due to the fact that overall income inequality in rural areas was much lower to begin with so that the income change required to change income bracket is smaller than in South Africa.
} 
Table 3 Quintile mobility matrix for African households in KwaZulu-Natal, 1993-1998

\section{a) Using raw data}

\begin{tabular}{|c|r|r|r|r|r|c|}
\hline & \multicolumn{7}{|c|}{ Quintile in 1998} \\
\hline 1993 quintile & \multicolumn{1}{|c|}{1} & \multicolumn{1}{|c|}{2} & \multicolumn{1}{c|}{3} & \multicolumn{1}{c|}{4} & \multicolumn{1}{c|}{5} & (row) total \\
\hline 1 & 33.2 & 24.3 & 18.2 & 14.4 & 9.9 & 100.0 \\
\hline 2 & 32.6 & 28.2 & 18.8 & 13.8 & 6.6 & 100.0 \\
\hline 3 & 17.8 & 21.7 & 28.3 & 23.3 & 8.9 & 100.0 \\
\hline 4 & 10.5 & 19.9 & 23.8 & 26.5 & 19.3 & 100.0 \\
\hline 5 & 6.1 & 6.1 & 10.5 & 22.1 & 55.3 & 100.0 \\
\hline
\end{tabular}

Source: own calculations on PSLSD/KIDS data

b) Using data purged by outliers from wage regressions

\begin{tabular}{|c|r|r|r|r|r|c|}
\hline & \multicolumn{7}{|c|}{ Quintile in 1998} \\
\hline 1993 quintile & \multicolumn{1}{|c|}{1} & \multicolumn{1}{c|}{2} & \multicolumn{1}{c|}{3} & \multicolumn{1}{c|}{4} & \multicolumn{1}{c|}{5} & (row) total \\
\hline 1 & 34.3 & 26.0 & 18.8 & 14.4 & 6.6 & 100.0 \\
\hline 2 & 32.6 & 29.3 & 18.8 & 14.4 & 5.0 & 100.0 \\
\hline 3 & 17.2 & 24.4 & 30.0 & 20.6 & 7.8 & 100.0 \\
\hline 4 & 11.1 & 15.5 & 23.8 & 33.7 & 16.0 & 100.0 \\
\hline 5 & 5.0 & 5.0 & 8.3 & 17.1 & 64.6 & 100.0 \\
\hline
\end{tabular}

Source: own calculations on PSLSD/KIDS data

When using expenditures, incomes without imputations, and predicted incomes or expenditures (see appendix for transition matrices), the general impression of high mobility is not changed considerably. ${ }^{18}$ In particular, the mobility matrix based on expenditures is quite similar to the (raw) income mobility matrix. There are, however, some differences in the extent of estimated mobility. The predicted income

\footnotetext{
${ }^{18}$ See also Maluccio, Haddad, and May (2000) who also report a transition matrix based on per capita expenditures using the same data.
} 
and expenditures based on our instruments show, not surprisingly, less mobility, particularly at the bottom of the distribution as the underlying household characteristics have not changed so much over the intervening five years. But this adjustment clearly exaggerates the extent of measurement error as any stochastic element in income determination is now eliminated although a good part of this stochastic variation is likely to be real rather than simply due to measurement error. ${ }^{19}$ Thus the relatively high mobility observed appears to be real rather than simply a result of measurement error (see also Fields et al 2002).

\section{The determinants of welfare changes: univariate analyses}

According to equation 1, change in an individual's well-being arises through changes in household income (via the numerator) which we call economic events and/or changes in household composition (via the denominator) which we refer to as demographic events. This distinction between welfare changes as the result of economic events and demographic events is often not considered but is of considerable relevance from a policy point of view. These economic events can be further broken down into economic events that relate to changes in income sources (e.g. through a changes in employment status, changes in sources of non-labour income) and changes in existing income sources.

Table 4 considers what is the biggest contributing "event" associated with a movement into and out of poverty (where poverty is defined as having income of less than R212 per adult equivalent per month in 1993 terms $^{20}$ ). Table 4 shows that more

${ }^{19}$ Carter and May (2001) assume that the stochastic variation of expenditures is all real which seems equally implausible as some measurement error is likely to play a role. Conversely, the transition matrix without imputations suggests the highest mobility of all estimates including considerable mobility across two, three, or even four quintiles, but here it is equally unclear whether this might be due to additional measurement error introduced by subtracting the housing income imputations.

${ }^{20}$ This is a relative poverty line that is chosen so as to make the poorest $40 \%$ of households "poor" in 1993. Often there may be more than one event that changed adult equivalent income. In this case, only the biggest one is recorded which is the one that had the largest percentage change in adult equivalent incomes. This we implement by first checking whether a demographic or an economic event had the biggest impact adult equivalent incomes. If it was an economic event, we then further examine which economic event has the largest impact on adult equivalent incomes. 
than one-quarter of households that moved into poverty did so because of a change in demographic composition. Nevertheless the majority of households became poor because of a fall in income. For nearly half of the households those income changes are associated with job-loss. A significant number of households, however, fell into poverty because of a decline in remittance income, non-labour earnings (usually the loss of a state pension or grant), a change in earnings, or falling incomes from smallscale agriculture.

Table 4 Main event associated with the movement of a household into and out of poverty (\% of households)

\begin{tabular}{|l|c|c|}
\hline & Into Poverty & Out of Poverty \\
\hline Fall/rise in money income as result of: & 27.4 & 23.6 \\
Demographic events & & \\
Income event, change in income from : & 18.8 & 12.0 \\
Head losing/getting job & 6.0 & 4.8 \\
Fall/rise in head's labour earnings & 15.4 & 16.8 \\
Other family member losing/getting job & 5.1 & 8.7 \\
Fall/rise in other household members' labour & 11.1 & 10.6 \\
earnings & 5.1 & 6.7 \\
Fall/rise in remittances & 0.9 & 3.4 \\
Fall/rise in non-labour income of head/spouse & & \\
Fall/rise in non-labour income of other household & 3.4 & 9.6 \\
members & 6.8 & 3.9 \\
Fall/rise in self-employment income & 100.0 & 100.0 \\
Fall/rise in farm income & 129 & 223 \\
\hline Total & & \\
\hline Observations & & \\
\hline
\end{tabular}

Source: own calculations on PSLSD/KIDS data.

Regarding movements out of poverty, one-fifth of households escaped poverty as a result of shedding household members. As in the case of movements into poverty, labour market changes were the most common reason for a significant change in household well-being. Again getting a job is much more important than changes in earnings (for those already working) for movements out of poverty. A significant 
proportion of households moved out of poverty because of an increase in state support or other non-labour income.

The results show some similarities to poverty dynamics in industrialized countries (e.g. Jenkins and Rigg, 2001). For example, demographic events are also more important for getting into poverty than getting out, and employment and earnings of the head and the spouse are particularly important among the income events. But there are also important differences. In particular, employment changes rather than wages in a particular job are more important in South Africa, and there is greater importance of remittances and agricultural incomes for movements into and out of poverty.

Altogether, demographic events and employment changes account for more than $60 \%$ of mobility into poverty, and over $50 \%$ out of poverty. Clearly, rapidly shifting household dynamics and employment changes in a situation of mass unemployment are the biggest determinants of mobility in this economy. These assignments hardly change when purging the data of outliers and change only slightly when imputations are taken out (not shown here). In the latter case, the importance of demographic and employment events rises even further, to $63 \%$ of movements into, and $55 \%$ of movements out of poverty.

Besides studying events associated with movements into and out of poverty, we also analysed important univariate determinants of income gains and losses. This is done in detail in Woolard, Klasen and Leibbrandt (2002) and will be briefly summarized here. Consistent with the findings above, important correlates of moving ahead are shedding household members, gaining employed people and losing unemployed people. More surprisingly, elderly household heads and female-headed households had a higher propensity to move ahead than middle-aged household heads or maleheaded households. Households with elderly heads (including many households headed by female elderly) are heavily reliant on state support, particularly the non- 
contributory social pensions, which is not only a secure form of income, but has increased appreciably in real terms since 1993 (Case and Deaton, 1998). ${ }^{21}$

While these univariate findings are suggestive, it is important to analyse the determinants of welfare changes in a multivariate setting, to which we presently turn.

\section{Modelling Determinants of Welfare Change: Multivariate Analysis}

In this section, we attempt to identify the factors which influence whether a household gained or lost over the five year period between the first and second wave of the household survey. ${ }^{22}$ The model that is proposed is derived directly from the standard household utility maximization model with adult equivalent household income as a money metric measure of utility. The underlying assumption of this model is that household income is a function of household assets (both physical and human) and the economic environment in which these assets can be utilized to generate income. In addition, the well-being of individual household members will depend additionally on the number of people who have to share these assets and the incomes derived from them.

Consequently, the dependent variable in our model is change in the real adult equivalent household income between 1993 and 1998.

A model of the following form was used:

$$
\Delta \ln \left(\frac{E_{i}}{A E_{i}}\right)=f\left(A_{i}, \Delta A_{i} ; R_{i} ; \Delta R_{i}\right)
$$

\footnotetext{
${ }^{21}$ We use our different income definitions and corrections for measurement error to see to what extent they drive the results (not shown here). It turns out that all the univariate relations discussed above remain qualitatively and even roughly quantitatively the same when we use our various controls for measurement error. The one difference is that the relationship between age of household head and changes in employment and mobility is weaker (although qualitatively the same) when expenditures are used. This might suggest that the elderly and those households that have increased the number of workers see the higher incomes as temporary and thus have not adjusted their expenditures to the full extent of their changes in incomes (see below). Altogether, these relations appear to be robust with respect methods of controlling for measurement error.
} 
where $E_{i}=$ real income of household $i$

$\mathrm{AE}_{i}=$ number of "adult equivalent" household members in household $i$

$A_{i}=\quad$ physical and human assets of household $i$

$\mathrm{R}_{i}=$ a set of characteristics which summarize the economic and demographic environment in which $i$ operates and thus determines the returns to those assets a household possesses

The regression was estimated separately for urban and rural households and allowed for further segmentation through the use of dummy variables for the gender of the household head and regional dummies for homeland/non-homeland households. In the urban regression we also include a dummy for the Durban metropolitan area.

Originally the model included income composition variables as proxies for a household's ability to respond to economic change since it has been argued that a diversified income base helps reduce household vulnerability to shocks (May et al., 1995). Since none of the variables were significant, they were dropped from the model. It was also attempted to include "shock" variables identified by the household - such as the occurrence of a fire, crop loss or death - but none of these were significant. $^{23}$

The first-difference variables include changes in human assets as well as demographic composition and employment changes as they might reasonably be seen as exogenous to the dependent variable. ${ }^{24}$

The initial income variable in the regression is a lagged endogenous variable which, given plausible assumptions about the correlation of errors (e.g. positive correlation of

\footnotetext{
${ }^{22}$ For a similar type of analysis for Cote d'Ivoire, see Grootaert and Kanbur (1990, 1995).

${ }^{23}$ See Maluccio, Haddad, and May (2000) for considering social capital as an other form of assets using these data. In their analysis, it only turned out to be a significant determinant of 1998 incomes; given the relatively limited number of variables considered, it is unclear, however, to what extent this is driven by left-out variable bias.

${ }^{24}$ We did not include changes in physical assets in the regression which are likely to be endogenous.
} 
errors over time in the reporting of incomes) will lead to biased estimates of the coefficients (e.g. Greene, 2000; Fields et al. 2002; Forbes, 2000). In addition, to the extent that a portion of the 1993 income is transitory, we will find a negative correlation between initial incomes and income change as households are reverting to their more permanent income. As we are not so much interested in these short-term fluctuations but more in medium-term mobility, we would ideally want to disregard these transitory income components. To address these issues, we are using instrumental variable techniques to predict initial incomes. ${ }^{25}$ In choosing instruments, we are guided by Fields et al. (2002, 2003) and rely particularly on headship and family characteristics as well as cluster average incomes (expenditures) for instruments. The instruments perform very well on the relevant tests, ${ }^{26}$ but a Hausman test (comparing the IV regressions with OLS) never finds endogeneity to be a problem. As the results do differ for certain covariates we will discuss the IV results as well, but do not report them separately. ${ }^{27}$

Table 10 summarizes the explanatory variables and shows their means and standard deviations. In the case of "initial conditions" variables, the figures pertain to 1993, while the change variables were calculated by subtracting 1993 values from 1998 values. Note that the standard deviation of the expenditure variable in 1993 is considerably lower than that of the income variable, suggesting a declining marginal propensity to consume (see below).

\footnotetext{
${ }^{25}$ It will not address all forms of measurement errors. For a discussion, see Fields et al. 2002.

${ }^{26}$ In particular, they significantly affect initial income while in a regression with initial income and the other exogenous regressors, they have no significant impact on the dependent variable (change in incomes or expenditures).

${ }^{27}$ They are available on request.
} 
Table $10 \quad$ Mean and standard deviation of variables used in model

\begin{tabular}{|c|c|c|c|c|}
\hline & \multicolumn{2}{|c|}{ Urban households } & \multicolumn{2}{|c|}{ Rural households } \\
\hline & Mean & Std dev. & Mean & $\begin{array}{l}\text { Std } \\
\text { dev. }\end{array}$ \\
\hline \multicolumn{5}{|l|}{ Income variables } \\
\hline Change in $\ln$ (adult equivalent income) & 0.48 & 1.02 & 0.26 & 1.18 \\
\hline Ln Adult equivalent income 1993 & 5.53 & 0.94 & 4.98 & 0.95 \\
\hline Change in $\ln$ (adult equivalent expenditure) & 0.005 & 0.68 & -0.26 & 0.68 \\
\hline Ln (adult equivalent expenditure) & 5.74 & 0.56 & 5.51 & 0.57 \\
\hline \multicolumn{5}{|l|}{ Human Capital variables } \\
\hline Household Size & 7.09 & 3.38 & 8.13 & 4.07 \\
\hline Share of children in household & 0.35 & 0.20 & 0.40 & 0.20 \\
\hline Share of female adults (under 60) in household* & 0.32 & 0.17 & 0.28 & 0.16 \\
\hline Share of male adults (under 65) in household* & 0.27 & 0.19 & 0.25 & 0.17 \\
\hline Average years of education of those not in school & 6.17 & 2.53 & 3.70 & 2.65 \\
\hline Age of household head & 52.25 & 14.09 & 52.80 & 14.44 \\
\hline \multicolumn{5}{|l|}{ Segmentation variables } \\
\hline Female headed households ( $1=$ female headed, 0 otherwise $)$ & 0.42 & 0.49 & 0.33 & 0.47 \\
\hline Homeland ( $1=$ former KwaZulu, 0 otherwise) & 0.71 & 0.45 & 0.92 & 0.27 \\
\hline Durban (1=Durban metropole, 0 otherwise) & 0.38 & 0.49 & & \\
\hline \multicolumn{5}{|l|}{ Physical capital variables } \\
\hline Home owner (1=home-owner, 0 otherwise) & 0.83 & 0.38 & 0.92 & 0.27 \\
\hline Number of durables owned by household & 4.81 & 2.91 & 3.07 & 2.29 \\
\hline Grazing or farming rights ( $1=$ rights, 0 otherwise) & 0.02 & 0.12 & 0.60 & 0.49 \\
\hline \multicolumn{5}{|l|}{ Labour market variables } \\
\hline Share of persons in household with jobs & 0.32 & 0.26 & 0.24 & 0.30 \\
\hline Share of unemployed persons in household & 0.26 & 0.27 & 0.19 & 0.24 \\
\hline \multicolumn{5}{|l|}{ Change variables between 1993 and 1998} \\
\hline Change in Household Size & -0.32 & 2.60 & -1.02 & 3.40 \\
\hline Change from male to female household head & 0.10 & 0.30 & 0.12 & 0.32 \\
\hline Change in the share of children in household & -0.020 & 0.20 & 0.010 & 0.22 \\
\hline Change in the share of female adults in household & 0.007 & 0.17 & 0.009 & 0.18 \\
\hline Change in the share of male adults in household & 0.001 & 0.18 & -0.033 & 0.20 \\
\hline Change in the average years of education & 0.32 & 2.41 & 0.47 & 2.34 \\
\hline Change in share of persons in household with jobs & 0.22 & 0.37 & 0.32 & 0.35 \\
\hline Change in share of unemployed persons in household & -0.05 & 0.34 & 0.01 & 0.30 \\
\hline $\mathbf{N}$ & 191 & & 656 & \\
\hline
\end{tabular}

Source: own calculations on PSLSD/KIDS data . *We choose different cut-offs for male and female elderly as the eligibility for the fairly generous non-contributory pensions follow these age cut-offs. 
Table 11 Determinants of change in In (adult equivalent income)

\begin{tabular}{|c|c|c|c|c|}
\hline & \multicolumn{2}{|c|}{ Urban households } & \multicolumn{2}{|c|}{ Rural households } \\
\hline $\begin{array}{l}\text { Adjusted } \mathrm{R}^{2} \\
\text { Number of observations }\end{array}$ & $\begin{array}{r}0.68 \\
191\end{array}$ & & $\begin{array}{r}0.55 \\
656\end{array}$ & \\
\hline & Coefficient & Std error & Coefficient & Std error \\
\hline Intercept & $2.93 * * *$ & 1.13 & $4.63 * * *$ & 0.67 \\
\hline $\begin{array}{l}\text { Income variable } \\
\ln \text { (adult equivalent income 1993) }\end{array}$ & $-0.84 * * *$ & 0.06 & $-0.95 * * *$ & 0.04 \\
\hline Human Capital variables & & & & \\
\hline Household Size & $-0.04 * *$ & 0.01 & $-0.02 * *$ & 0.01 \\
\hline Share of children in household & 0.19 & 0.70 & $-1.49 * * *$ & 0.37 \\
\hline Share of female adults (under 60) in household* & $1.06^{*}$ & 0.62 & $-1.32 * * *$ & 0.36 \\
\hline Share of male adults (under 65) in household* & $1.11 *$ & 0.77 & $-0.67 * *$ & 0.35 \\
\hline Average years of education of those not in school & $0.12 * * *$ & 0.02 & $0.12 * * *$ & 0.02 \\
\hline Age of household head & 0.001 & 0.02 & 0.001 & 0.01 \\
\hline Squared age of household head & 0.0001 & 0.0002 & 0.0001 & 0.0001 \\
\hline Segmentation variables & & & & \\
\hline $\begin{array}{l}\text { Female headed households ( } 1=\text { female headed, } 0 \\
\text { otherwise) }\end{array}$ & $-0.19 *$ & 0.11 & $-0.24 * * *$ & 0.08 \\
\hline Homeland (1=former KwaZulu, 0 otherwise) & 0.07 & 0.10 & 0.36 *** & 0.13 \\
\hline Durban (1=Durban metropole, 0 otherwise) & $0.18 * *$ & 0.10 & & \\
\hline Physical capital variables & & & & \\
\hline Home owner (1=home-owner, 0 otherwise) & -0.07 & 0.11 & 0.07 & 0.13 \\
\hline Number of durables owned by household & $0.05 * * *$ & 0.01 & $0.04 * *$ & 0.02 \\
\hline Grazing or farming rights ( $1=$ rights, 0 otherwise) & 0.27 & 0.20 & 0.06 & 0.08 \\
\hline Labour market variables & & & & \\
\hline Share of persons in household with jobs & $1.00 * * *$ & 0.26 & $1.15 * * *$ & 0.21 \\
\hline Share of unemployed persons in household & -0.51 & 0.42 & $-0.86 * * *$ & 0.21 \\
\hline Change variables between 1993 and 1998 & & & & \\
\hline Change in household size & -0.01 & 0.02 & 0.01 & 0.01 \\
\hline Change from male to female head & $-0.41 * *$ & 0.20 & $-0.33 * * *$ & 0.09 \\
\hline Change in the share of children in household & $-0.81 * * *$ & 0.30 & $-0.84 * * *$ & 0.23 \\
\hline Change in the share of female adults in household & -0.22 & 0.38 & $0.42 *$ & 0.30 \\
\hline Change in the share of male adults in household & $0.85 * *$ & 0.37 & 0.19 & 0.30 \\
\hline Change in the average years of education & $0.12 * * *$ & 0.02 & $0.12 * * *$ & 0.02 \\
\hline Change in share of persons in household with jobs & $1.00 * * *$ & 0.26 & $0.88 * * *$ & 0.17 \\
\hline $\begin{array}{l}\text { Change in share of unemployed persons in } \\
\text { household }\end{array}$ & $-0.57 * *$ & 0.29 & $-0.90 * * *$ & 0.19 \\
\hline
\end{tabular}

Source: own calculations on PSLSD/KIDS data

Note: Coefficients in bold are significant. Those denoted with * are significant at a $10 \%$ level, with ** at a $5 \%$ level, and with $* * *$ at the $1 \%$ level (one-tail test). We choose different cut-offs for male and female elderly as the eligibility for the fairly generous non-contributory pensions follow these age cutoffs. Left-out categories are the share of elderly and the change in the share of elderly. 
Table 11 presents the results for the income change regressions run separately for rural and urban households. The models both fit very well, with the urban model explaining slightly more of the variation in the data than the rural model. Many of the initial conditions variables as well as of the change variables have a significant impact on income change, a finding not replicated in many other countries. ${ }^{28}$ In both models, 1993 income has a negative coefficient, suggesting a strong tendency towards the mean (or convergence of adult equivalent incomes). Thus the higher adult equivalent income was in 1993, the more likely the household was to experience a drop in welfare over the five year period. This suggests that there are large transitory components in the income of most households, which is consistent with the picture of high mobility which was presented above. It would also be consistent with typical findings about measurement error which also tend to produce regression towards the mean (Bound et al, 2001); we examine this issue further below.

Among the human capital and household composition variables, we find that large initial household sizes reduce adult equivalent income in urban and rural areas. This suggests a demographic poverty trap with large households having greater difficulty in improving their economic position. Household composition affects mobility differently in rural and urban areas. A large share of children in rural areas, and increases in that share in both rural and urban areas lead to falling income levels. Thus it appears that the demographic poverty trap is particularly severe if household size is large due to presence of many children. In urban areas, a high share of female and male adults improves prospects for positive income change, and only an increase in the number of children significantly reduces these prospects. Both findings are quite intuitive. In rural areas, however, only a large share of elderly in 1993 (the omitted category) greatly improves the chance of increasing incomes, while an increase in the share of children reduces it. This points to the great importance of oldage pensions as an income source in rural areas, while the presence of adult males is not very important due to poor employment opportunities there.

\footnotetext{
${ }^{28}$ For example, Fields et al. (2003) find that the change variables have little impact on income change in Venezuela, Spain, and Indonesia, while they also find some of them to significantly influence
} 
High initial education and change in education significantly improves upward mobility in both urban and rural areas. This represents evidence of a second poverty trap, this time associated with education. While improving education is a way out of poverty, those who started with low education will have an additional hurdle to overcome.

Regarding physical assets, the number of durables owned in the initial period has a significant positive impact on subsequent income change. Those with poor household assets have greater difficulty in improving their incomes, thus representing a third poverty trap. ${ }^{29}$

Turning to the segmentation variables, homeland households increased their wellbeing by more than their non-homeland counterparts. After controlling for all other factors, female headed households fare worse from male-headed households in both urban and rural areas. Thus the univariate finding of female-headed households improving their situation more often than male-headed households does not carry over to the multivariate analysis. Moreover, a change from a male-headed to a femaleheaded household is associated with a fall in income in both urban and rural areas. This might be due to the uncertain nature of remittances sent by absent heads as well as the impact of a male head having passed away. The age of the household head was also not significant.

The employment variables came in very strongly, with large and significant coefficients. Both the initial state variables and the change variables were important predictors of change in welfare. While the change variables are eminently plausible, the initial conditions variables are more worrying. They suggest that households with few initially employed members and large numbers of unemployed are finding it more difficult to improve their incomes subsequently. This points to a fourth poverty trap, this time associated with the labour market, suggesting significant segmentation and

income change in South Africa.

\footnotetext{
${ }^{29}$ The variable for home ownership was not significant, which probably reflects that it was a poor measure: the vast majority of households reported that they owned their homes, but this does not reflect the vast variation in housing type and value.
} 
disadvantages for those from households with little labour market experience. Interestingly, the effect of an additional employed person more than compensates for the acquisition of an unemployed person. The coefficient of the share of persons with jobs in 1993 is about the same size as the coefficient of an increase in these shares, which is surprising given that what is being modelled is the change in welfare.

It is particularly worrying to see four types of poverty traps emerging separately in this multivariate framework. Many households might be subject to all four of these traps at the same time as they have a large household, poor asset base, poor average education, and a low share of employed and a high share of unemployed in 1993. Conversely, the great importance and significance of the change variables point to the possibility of poor households to escape poverty. The most important factors that help are improvements in education and employment, and a reduced number of children.

Also here, we consider our alternative specifications to check to what extent these results might be driven by measurement error. When we use the purged income data set (not shown here), the changes are minute and virtually identical to the ones reported above. The purged regressions do have a slightly better fit, as one would expect. The regression towards the mean is, surprisingly, larger than previously suggesting that measurement error is not so much behind this.

When using the expenditure regressions (Table 12), the results are similar to the income regressions. This is surprising given that there were significant differences in levels and trends to the income variables. In particular, there is a similarly strong negative effect of initial expenditures, suggesting strong regression towards the mean. This indicates that expenditures vary not by much less than incomes over time, suggesting that households are not able to smooth consumption very successfully. Moreover, we also find the four poverty traps associated with having a large household, having few assets, being poorly educated, and having few employed people in the household in the initial period. The employment variables are less important in general in the expenditure regressions, confirming what we found in Woolard et al. (2002). In contrast, the household size and change in household size effect is larger and more significant in urban and rural areas. Regarding the change 
variables, improvements in education, reducing household size and reducing the share of unemployed are associated with improvements in expenditures. ${ }^{30}$

We also consider the income regressions without imputations (not shown but available on request). The results are qualitatively very similar again. We find strong regression towards the mean, we find poverty traps associated with poor education and initial employment. The trap associated with household size is not significant in rural areas and in general the model has a worse fit.

Lastly, we considered the three types of models but instrumented the initial income variable. In the income change regression, they actually have little impact on any of the coefficients, except that many are now not as well determined and therefore less significant. $^{31}$ In the expenditure change regression, all four poverty traps remain significant. While the regression towards the mean is not changed much in urban areas, it is significantly reduced in rural areas. In the income regression without imputations, the results are also not much affected by the use of instrumental variables.

\footnotetext{
${ }^{30}$ There are other minor changes in the importance of some variables. Also note that the fit of the expenditure regressions is generally poorer than the income regressions.

${ }^{31}$ As a result, only the employment and the education poverty traps remain significant, while the ones relating to household size and initial assets are no longer significant, although the coefficients have the expected signs.
} 
Table 12 Determinants of change in In (adult equivalent expenditures)

\begin{tabular}{|c|c|c|c|c|}
\hline & \multicolumn{2}{|c|}{ Urban households } & \multicolumn{2}{|c|}{ Rural households } \\
\hline $\begin{array}{l}\text { Adjusted } \mathrm{R}^{2} \\
\text { Number of observations }\end{array}$ & $\begin{array}{r}0.54 \\
192\end{array}$ & & $\begin{array}{r}0.47 \\
657\end{array}$ & \\
\hline & Coefficient & Std error & Coefficient & Std error \\
\hline Intercept & $6.23 * * *$ & 0.88 & $4.17 * * *$ & 0.41 \\
\hline Income variable & & & & \\
\hline ln (adult equivalent expenditures 1993) & $-1.03 * * *$ & 0.09 & $-0.86 * * *$ & 0.04 \\
\hline Human Capital variables & & & & \\
\hline Household Size & $-\mathbf{0 . 0 8} * * *$ & 0.01 & $-0.05 * * *$ & 0.01 \\
\hline Share of children in household & -0.80 & 0.53 & -0.24 & 0.25 \\
\hline Share of female adults (under 60) in household* & $-0.67 * *$ & 0.35 & $-0.79 * * *$ & 0.26 \\
\hline Share of male adults (under 65) in household* & $-1.07 * *$ & 0.43 & -0.21 & 0.26 \\
\hline Average years of education of those not in school & $0.07 * * *$ & 0.02 & $\mathbf{0 . 0 8} * * *$ & 0.01 \\
\hline Age of household head & 0.01 & 0.01 & -0.001 & 0.01 \\
\hline Squared age of household head & $-0.0001 *$ & 0.0001 & 0.00005 & 0.0001 \\
\hline Segmentation variables & & & & \\
\hline $\begin{array}{l}\text { Female headed household in } 1993 \text { ( } 1=\text { female } \\
\text { headed, } 0 \text { otherwise) }\end{array}$ & -0.07 & 0.09 & $-0.10 * *$ & 0.05 \\
\hline Homeland (1=former KwaZulu, 0 otherwise) & 0.02 & 0.18 & -0.05 & 0.10 \\
\hline Durban (1=metropole, 0 otherwise) & 0.13 & 0.14 & & \\
\hline Physical capital variables & & & & \\
\hline Home owner (1=home-owner, 0 otherwise) & 0.09 & 0.09 & $0.20 * * *$ & 0.07 \\
\hline Number of durables owned by household & $0.07 * * *$ & 0.01 & $\mathbf{0 . 0 4} * * *$ & 0.01 \\
\hline Grazing or farming rights ( $1=$ rights, 0 otherwise) & 0.07 & 0.13 & $0.10 * *$ & 0.05 \\
\hline Labour market variables & & & & \\
\hline Number of persons in household with jobs & 0.24 & 0.20 & $0.39 * * *$ & 0.12 \\
\hline Number of unemployed persons in household & $-0.38 * *$ & 0.19 & $-0.52 * * *$ & 0.11 \\
\hline Change variables between 1993 and 1998 & & & & \\
\hline Change in Household Size & $-0.08 * * *$ & 0.02 & $-0.03 * * *$ & 0.01 \\
\hline Change from male to female head & -0.10 & 0.15 & $-0.16 * * *$ & 0.06 \\
\hline Change in the share of children in household & 0.17 & 0.26 & 0.08 & 0.17 \\
\hline Change in the share of female adults in household & -0.11 & 0.33 & $0.24 *$ & 0.16 \\
\hline Change in the share of male adults in household & 0.31 & 0.41 & 0.01 & 0.17 \\
\hline Change in the average years of education & $0.05 * *$ & 0.03 & $0.07 * * *$ & 0.01 \\
\hline Change in share of persons in household with jobs & 0.14 & 0.15 & $0.41 * * *$ & 0.11 \\
\hline $\begin{array}{l}\text { Change in share of unemployed persons in } \\
\text { household }\end{array}$ & $-0.32 * *$ & 0.13 & $-0.37 * * *$ & 0.09 \\
\hline
\end{tabular}

Source: own calculations on PSLSD/KIDS data

Note: Coefficients in bold are significant. Those denoted with * are significant at a $10 \%$ level, with $* *$ at a $5 \%$ level, and with $* * *$ at the $1 \%$ level (one-tail test). *We choose different cut-offs for male and female elderly as the eligibility for the fairly generous non-contributory pensions follow these age cutoffs. Left-out categories are the share of elderly and the change I the share of elderly. 
The results suggest, quite robustly, that transitory incomes play a large role in determining household welfare. Those found to be poor in the initial period are likely, on average, to improve their income position significantly. Conversely, there are four types of poverty traps associated with poor initial education, assets, employment, and large household size. Which effect is, on average, stronger? Table 13 tries to address this question. At the mean, it evaluates the impact of a simultaneous deterioration of one standard deviation of the initial income variable, as well as the four variables associated with the poverty traps. In the first column, it thus asks, by how much a mean household's adult equivalent income will change between 1993 and 1998 if initial income, number of durables, education, and the share of jobs is each reduced by one standard deviation, while the initial household size and share of unemployed is increased by one standard deviation. This is done for the three income concepts, urban and rural households, and also an IV regression that instruments for initial income. The positive impact of lowering initial income is substantial, but it is invariably dominated by the negative impact of poorer initial education, assets, employment, and household size. At the mean, this change would reduce incomes by about $12-14 \%$ in rural and urban areas, where poor initial education and employment are quantitatively most important. Changing to the IV regression hardly changes the results in urban areas, but reduces the convergence effect as well as the size of the poverty traps in rural areas. Using the expenditure regressions, the negative impact of the poverty traps is also larger than the convergence effect as the impact of the combined simulation would lower adult equivalent expenditures by between 15-20\%. The convergence effect is much smaller (due to the reduced standard deviation in expenditures observed in Table 10), and the household size poverty trap is quantitatively much larger. These results suggest that, regardless of the specification and the control for endogeneity, the impact of poor initial conditions is larger than the benefit of regression towards the mean. $^{32}$

\footnotetext{
${ }^{32}$ The instrumented expenditure regressions show very similar results, with the net effect being slightly smaller (12\% in urban and $18 \%$ in rural areas).
} 
One should also point out that these results reflect average effects. It may well be the case that some households are transitorily poor and therefore experience rapid regression towards the mean and no poverty traps, while others are chronically poor, trapped by the four poverty traps discussed. Also, these effects may differ at different parts of the distribution which merits further investigation. ${ }^{33}$

Table 13: Convergence versus Poverty Traps

\begin{tabular}{|l|r|r|r|r|r|r|r|r|}
\hline & \multicolumn{7}{l|}{ Urban } & \multicolumn{1}{l|}{ Rural } \\
\hline & Income & $\begin{array}{l}\text { Income } \\
\text { Instr. }\end{array}$ & Expend. & $\begin{array}{l}\text { Income } \\
\text { w/o Imp. }\end{array}$ & Income & $\begin{array}{l}\text { Income } \\
\text { Instr. }\end{array}$ & Expend. & $\begin{array}{l}\text { Income } \\
\text { w/o Imp. }\end{array}$ \\
\hline $\begin{array}{l}\text { Initial } \\
\text { Income }\end{array}$ & $0.79 * * *$ & $0.86 * * *$ & $0.58 * * *$ & $0.70 * * *$ & $0.90 * * *$ & $0.62 * * *$ & $0.49 * * *$ & $0.81 * * *$ \\
\hline $\begin{array}{l}\text { Household } \\
\text { Size }\end{array}$ & $-0.12 * *$ & $-0.13 *$ & $-0.25 * * *$ & $-0.16 * *$ & $-0.07 * *$ & -0.04 & $-0.19 * * *$ & -0.03 \\
\hline Durables & $-0.13 * * *$ & $-0.14 *$ & $-0.19 * * *$ & $-0.16 * * *$ & $-0.09 * *$ & -0.04 & $-0.10 * * *$ & $-0.08 *$ \\
\hline Education & $-0.29 * * *$ & $-0.31 * * *$ & $-0.18 * * *$ & $-0.27 * * *$ & $-0.32 * * *$ & $-0.26 * * *$ & $-0.22 * * *$ & $-0.24 * * *$ \\
\hline $\begin{array}{l}\text { Share } \\
\text { Employed }\end{array}$ & $-0.26 * * *$ & $-0.29 * *$ & -0.06 & $-0.21 * *$ & $-0.34 * * *$ & $-0.26 * * *$ & $-0.12 * * *$ & $-0.41 * * *$ \\
\hline $\begin{array}{l}\text { Share } \\
\text { Unemployed }\end{array}$ & -0.14 & -0.16 & $-0.10 * *$ & 0.03 & $-0.20 * * *$ & -0.12 & $-0.09 * * *$ & $-0.20 * * *$ \\
\hline Total & -0.15 & -0.16 & -0.21 & -0.08 & -0.12 & -0.09 & -0.23 & -0.16 \\
\hline $\begin{array}{l}\text { Change } \\
\text { Mean }\end{array}$ & -34.55 & -37.75 & -57.95 & -16.07 & -16.88 & -12.92 & -50.21 & -20.35 \\
\hline$\%$ Change & $-13.8 \%$ & $-15.0 \%$ & $-18.6 \%$ & $-7.5 \%$ & $-11.7 \%$ & $-8.9 \%$ & $-20.3 \%$ & $-14.5 \%$ \\
\hline
\end{tabular}

Note: The table compares the impact of a standard deviation deterioration in the stated 1993 covariates on the change in per adult equivalent income (or expenditure or income without imputations) between 1993 and 1998. Deterioration means a simultaneous increase in household size and in the share of unemployed and a decrease in the average education, employment shares, durable goods, and initial income. The last two rows then evaluate the combined impact, evaluated at mean income in 1993, in absolute and relative terms. * refers to $10 \%$ significance level, ** to a $5 \%$ significance level, and $* * *$ to a $1 \%$ significance level (one-tailed test).

\section{Concluding comments}

In this paper we have examined the determinants of household income mobility in among Africans in South Africa's most populous province of KwaZulu Natal between 1993 and 1998. We find a fairly high degree of mobility, compared to industrialized and also most developing countries. Part of this mobility might be spurious and due to measurement error but our various attempts to correct for this problem do not drastically alter the impression of high mobility. When disaggregating the observed mobility, we

\footnotetext{
${ }^{33}$ Two directions of further research are promising. One is to consider quantile regressions to see whether the average effects also hold at different points in the distribution and the other is to split the sample into different groups that might be able to distinguish the chronic from the transitory poor. Having a third wave would be very helpful here.
} 
find that demographic changes and employment changes are the most important determinants of mobility. Both is related to high unemployment and a resulting great deal of labour market churning as well as to great demographic fluidity which is related both to fertility and mortality, but also to shifting household boundaries. Our multivariate analysis confirms the importance of demographic and employment effects. Apart from a strong tendency of a regression towards the mean, which should facilitate mobility also for the poor, we identify four poverty traps that hinder the advancement of the poor. They relate to large initial household size, poor initial assets, poor initial education, and poor initial participation in the labour market. These poverty traps appear to quantitatively dominate the effect of the regression towards the mean. Conversely, improvements in education, reductions in household size (particularly in the number of children), and improved employment opportunities appear to be the most promising ways to improve incomes. ${ }^{34}$ Overcoming the poverty traps and strengthening the factors associated with improved incomes will be the main challenges facing policy-makers in their efforts to combat poverty.

\footnotetext{
34 This result, while suggestive, may also be influenced by unobserved heterogeneity which is correlated with the regressors used. To investigate this, one needs to control for household-specific fixed effects which necessitates a panel of at least 3 waves.
} 


\section{References}

Aaberge, R., Bjoklund. A., Janti, M., Palme. M., Pedersen, P., Smith N. and Wennemo, T. 1996. Income inequality mobility and income mobility in the Scandinavian countries compared to the United States. University of Stockholm Discussion Paper no. 98. University of Stockholm.

Bogomolova, T. and Tapilina, V. 1999. Income mobility in Russia in the mid-1990s. Economic Education and Research Consortium Russian Economic Research Program Working Paper 99/11.

Bound, J., Ch. Brown, G. Duncan, and W. Rodgers. 1994: Evidence on the Validity of Crosssectional and Longitudinal Labor Market Data. Journal of Labor Economics 12: 345368.

Bound, J. Ch. Brown, and N. Methiowetz. 2001. Measurement Error in Survey Data. Handbook of Econometrics, Volume 5: 3705-3843. Amsterdam: North-Holland.

Bound, J. and A. B. Krueger. 1991. The Extent of Measurement Error in Longitudinal Earnings Data: Do two Wrongs make a Right? Journal of Labor Economics 9: 1-25.

Burkhauser, R. and Poupore, J. 1996. A cross-national comparison of permanent inequality in the United States and Germany. Review of Economics and Statistics LXXIX(1): 10-18.

Cantó, O. 2000. Income mobility in Spain: how much is there? Review of Income and Wealth 46: 85-102.

Case, A and Deaton, A. 1998. Large cash transfers to the elderly in South Africa. Economic Journal 108:1330-61

Carter, M. and J. May. 2001. One Kind of Freedom. World Development 29: 1987-2006.

Cowell, F. and C. Schluter. 1998a. Income Mobility: A Robust Approach. STICERD Discussion Paper No. DARP 37. London: LSE.

Cowell, F. and C. Schluter. 1998b. Measuring Income Mobility with Dirty Data. CASE/16. London: LSE.

Deaton, A. 1997. The Analysis of Household Surveys. Baltimore: Johns Hopkins University Press.

Dercon, S. and P. Krishnan. 2000. Vulnerability, Seasonality, and Poverty in Ethiopia. Journal of Development Studies 36: 25-53.

Eriksson, I. And T. Pettersson. 2000. Income Distribution and Income Mobility- Recent Trends in Sweden. In Hauser, R. and I. Becker (eds.) The Personal Distribution of Income in an Historical Perspective. Berlin: Springer, 158-176.

Fabig, H. 2000. Labor Income Mobility- Germany, the USA and Great Britain Compared. In Hauser, R. and I. Becker (eds.) The Personal Distribution of Income in an Historical Perspective. Berlin: Springer, 31-56.

Fields, G.S. 2001. Distribution and development: a new look at the developing world. Cambridge: MIT Press.

Fields, G.S. 1998. Accounting for income inequality and its change. Mimeo. Ithaca: Cornell University.

Fields, G.S., Cichello,P., Freije, S., Menendez, M. and Newhouse, D. 2002. For richer or for poorer? Evidence from Indonesia, South Africa, Spain and Venezuela. Mimeographed, Cornell University.

Fields, G. D. and E. A. Ok. 1999. The Measurement of Income Mobility: An introduction to the literature. In Silber, J. (ed.) Handbook of Income Inequality Measurement. Boston: Kluwer, 557-599.

-----. 2003. Household Income Dynamics. A Four Country Study. Journal of Development Studies (forthcoming). 
Forbes, Kristine. 2000. A Reassessment of the Relationship between Inequality and Growth. American Economic Review 90: 869-887.

Gottschalk, P. 1982. Earnings mobility: permanent change or transitory fluctuations? Review of Economics and Statistics 64:450-456.

Greene, W. H. 2000. Econometric Analysis. Fourth Edition.

Grootaert, C. and Kanbur, R. 1990. Policy-oriented analysis of poverty and the social dimensions of structural adjustment: a methodology and proposed application to Côte d'Ivoire, 1985-88. Washington DC The World Bank.

Grootaert, C. and R. Kanbur. 1995. The Lucky Few amidst Economic Decline: Distributional Change in Cote d'Ivoire as seen through Panel Data Sets. Journal of Development Studies 31: 603-619.

Glewwe, P., Gragnolati, M. and Zaman, H. forthcoming. Who gained from Vietnam's boom in the 1990's? An analysis of poverty and inequality trends. Economic Development and Cultural Change (forthcoming)

Greene, W. 2000. Econometric Analysis. New York: Prentice Hall.

Jalan, J. and M. Ravallion. 2000. Is Transient Poverty Different? Evidence for Rural China. Journal of Development Studies 36: 82-99.

Jarvis, S. and Jenkins, S. 1995. Do the poor stay poor? New evidence about income dynamics from the British household panel survey. Occassional Paper 95-2, ESRC Research Centre on Micro-social Change.

Jarvis, S., Jenkins, S.P. 1997. Low income dynamics in 1990s Britain. Fiscal Studies 18: 1-20.

Jarvis, S., Jenkins, S.P. 1998. How much income mobility is there in Britain? Economic Journal, 108: 428-443.

Jenkins, S. and J. Rigg. 2001. The Dynamics of Poverty in Britain. Department for Work and Pensions Resaerch Report No. 157. London: Corporate Document Services.

Justino, P. and J. Lichfield. Poverty Dynamics in Rural Vietnam: Winners and Losers during Reform. Paper presented at the $27^{\text {th }}$ Biannual Conference of the IARIW, Stockholm, August, 2002.

Klasen, S. 2000. Measuring Poverty and Deprivation in South Africa. Review of Income and Wealth 46: 33-58.

Klasen, S. 2002. Social, Economic, and Environmental Limits for the Newly Enfranchised in South Africa? Economic Development and Cultural Change 50:607-642..

Klasen, S. and Woolard, I. 2001. Surviving Unemployment without State Support. Unemployment and Household Formation in South Africa. CESifo Working Paper No. 533.

Leibbrandt, M.V. and Woolard, I.D. 1999. A comparison of poverty in South Africa's nine provinces. Development Southern Africa 16(1): 37-54.

Lillard, L.A. and Willis, R.J. 1978. Dynamic aspects of earnings mobility. Econometrica 46: 985-1012.

Maluccio, J. L. Haddad, and J.May 2000. Social Capital and Household Welfare in South Africa, 1993-1998. Journal of Development Studies 36: 54-81.

McCulloch, N. and M. Calandrino. 2002. Vulnerability and Chronic Poverty in Rural Sichuan. Paper presented at the $27^{\text {th }}$ Biannual Conference of the IARIW, Stockholm, August, 2002.

May, J., Carter, M. and Posel, D. 1995. The composition and persistence of poverty in rural South Africa: an Enntitlements approach. Land and Agriculture Policy Centre Policy Paper No. 15, Land and Agriculture Policy Centre. 
Nee, Viktor. 1994. The Emergence of a Market Society: Changing Mechanisms of Stratification in China. Working Papers on Transitions from State Socialism. 94.1 Ithaca: Cornell University.

Piketty, Th. 2000. Theories of Persistent Inequality and Intergenerational Mobility. Handbook of Income Distribution, Vol. 1: 429-476. Amsterdam: North-Holland.

Ravallion, M. 1992. Poverty comparisons: a guide to concepts and methods. Living Standards Measurement Study Working Paper 88. Washington DC World Bank.

Republic of South Africa. 1994. White paper on reconstruction and development. Pretoria: Government Printer.

Roberts, B. 2000. Chronic and Transitory Poverty in Post-Apartheid South Africa: Evidence from KwaZulu-Natal. Mimeograph, University of Natal.

Scott, C. D. 2000. Mixed Fortunes: A Study of Poverty Mobility among Small Farm Households in Chile, 1968-1986. Journal of Development Studies 36: 155-180.

Woolard, I. Klasen, S and Leibbrandt, M. "Income mobility and household dynamics in South Africa: the case of Africans in KwaZulu-Natal. Labour Markets and Social Frontiers, 2:5-11.

World Bank. 2001. World Development Report. New York: Oxford University Press. 
Table A3: Quintile mobility matrix for African households in KwaZulu-Natal a) Expenditures

\begin{tabular}{|c|c|c|c|c|c|c|}
\hline & \multicolumn{7}{|c|}{ Quintile in 1998 } \\
\hline 1993 quintile & 1 & 2 & 3 & 4 & 5 & (row) total \\
\hline 1 & 36.5 & 26.0 & 22.0 & 11.0 & 4.5 & 100.0 \\
\hline 2 & 32.0 & 24.5 & 18.0 & 17.5 & 8.0 & 100.0 \\
\hline 3 & 14.5 & 26.5 & 21.0 & 24.0 & 14.0 & 100.0 \\
\hline 4 & 12.5 & 17.0 & 22.5 & 23.0 & 22.0 & 100.0 \\
\hline 5 & 4.5 & 6.00 & 13.5 & 24.5 & 51.5 & 100.0 \\
\hline
\end{tabular}

b)Incomes without imputations

\begin{tabular}{|c|c|c|c|c|c|c|}
\hline & \multicolumn{7}{|c|}{ Quintile in 1998} \\
\hline 1993 quintile & 1 & 2 & 3 & 4 & 5 & (row) total \\
\hline 1 & 33.5 & 23.5 & 17.7 & 14.1 & 11.2 & 100.0 \\
\hline 2 & 30.2 & 30.2 & 17.8 & 13.0 & 8.9 & 100.0 \\
\hline 3 & 17.8 & 20.1 & 25.4 & 23.1 & 13.6 & 100.0 \\
\hline 4 & 8.3 & 20.1 & 26.6 & 26.0 & 18.9 & 100.0 \\
\hline 5 & 10.7 & 5.9 & 12.4 & 23.7 & 47.3 & 100.0 \\
\hline
\end{tabular}

c)Expenditures without imputations

\begin{tabular}{|c|c|c|c|c|c|c|}
\hline & \multicolumn{7}{|c|}{ Quintile in 1998} \\
\hline 1993 quintile & 1 & 2 & 3 & 4 & 5 & (row) total \\
\hline 1 & 32.4 & 28.2 & 20.0 & 13.0 & 6.5 & 100.0 \\
\hline 2 & 32.0 & 21.3 & 20.7 & 14.2 & 11.8 & 100.0 \\
\hline 3 & 15.4 & 24.9 & 19.5 & 21.3 & 18.9 & 100.0 \\
\hline 4 & 13.6 & 17.8 & 23.7 & 22.5 & 22.5 & 100.0 \\
\hline 5 & 7.10 & 7.7 & 16.0 & 29.0 & 40.2 & 100.0 \\
\hline
\end{tabular}

\section{d)Predicted Incomes}

\begin{tabular}{|c|c|c|c|c|c|c|}
\hline & \multicolumn{7}{|c|}{ Quintile in 1998 } \\
\hline 1993 quintile & 1 & 2 & 3 & 4 & 5 & (row) total \\
\hline 1 & 43.3 & 31.3 & 14.4 & 5.5 & 5.5 & 100.0 \\
\hline 2 & 27.5 & 27.5 & 26.0 & 13.5 & 5.5 & 100.0 \\
\hline 3 & 16.4 & 21.9 & 23.4 & 28.4 & 10.0 & 100.0 \\
\hline 4 & 9.5 & 13.0 & 24.0 & 30.5 & 23.0 & 100.0 \\
\hline 5 & 3.5 & 6.0 & 12.4 & 21.9 & 56.2 & 100.0 \\
\hline
\end{tabular}


e)Predicted Expenditures

\begin{tabular}{|c|c|c|c|c|c|c|}
\hline & \multicolumn{7}{|c|}{ Quintile in 1998} \\
\hline 1993 quintile & 1 & 2 & 3 & 4 & 5 & (row) total \\
\hline 1 & 48.3 & 23.9 & 16.4 & 7.0 & 4.5 & 100.0 \\
\hline 2 & 29.0 & 30.5 & 22.5 & 14.5 & 3.5 & 100.0 \\
\hline 3 & 12.9 & 27.9 & 26.9 & 19.4 & 12.9 & 100.0 \\
\hline 4 & 8.5 & 14.0 & 20.5 & 35.5 & 21.5 & 100.0 \\
\hline 5 & 1.5 & 3.5 & 13.9 & 23.4 & 57.7 & 100.0 \\
\hline
\end{tabular}

